Old Dominion University

ODU Digital Commons

\title{
Time Management Matters: Online Faculty Perceptions of Helpfulness of Time Management Strategies
}

\author{
Beth Oyarzun \\ Florence Martin \\ Robert L. Moore \\ Old Dominion University
}

Follow this and additional works at: https://digitalcommons.odu.edu/stemps_fac_pubs

Part of the Online and Distance Education Commons, and the Science and Mathematics Education Commons

\section{Original Publication Citation}

Oyarzun, B., Martin, F., \& Moore, R. L. (2020). Time management matters: Online faculty perceptions of helpfulness of time management strategies. Distance Education, 1-22. doi:10.1080/

01587919.2020 .1724773

This Article is brought to you for free and open access by the STEM Education \& Professional Studies at ODU Digital Commons. It has been accepted for inclusion in STEMPS Faculty Publications by an authorized administrator of ODU Digital Commons. For more information, please contact digitalcommons@odu.edu. 


\title{
Time management matters: Online faculty perceptions of helpfulness of time management strategies
}

\author{
Beth Oyarzun (iD) ${ }^{a}$, Florence Martin (iD) ${ }^{a}$, and Robert L. Moore $\mathbb{D i D}^{\mathrm{b}}$
}

Q1 aEducational Leadership, The University of North Carolina at Charlotte, Charlotte, North Carolina, USA;

\begin{abstract}
This study examined 256 faculty survey responses to determine perceptions of helpfulness of 24 time management strategies grouped into four categories defined by Berge (1995) as managerial, pedagogical, technical, and social. Findings indicate that establishing clear and specific expectations $(M=4.32)$ was perceived as the most helpful, followed by organizing content into modules or units $(M=4.28)$, which were both pedagogical time management strategies. Participants additionally responded to two open-ended items regarding the most and least helpful time management strategies. The open-ended responses were consistent with the survey findings. The relationship between faculty demographic factors and strategies showed that receiving training to teach online affected the faculty perceptions of technical time management strategies.
\end{abstract}

\section{ARTICLE HISTORY}

Received 13 May 2019

Final version received 30 Jan 2020

\section{KEYWORDS}

online faculty; time management; perceptions; helpfulness

\section{Introduction}

Seaman et al. (2018) reported an increase in distance education enrollment for the 14th year in a row, citing that the growth over the previous year had been larger than the previous few years. However, there are still barriers to faculty adoption of online teaching practices. Loyd et al. (2012) explored faculty-perceived barriers to online teaching and identified four themes: interpersonal, institutional, training and technology, and cost-benefit barriers. Faculty identified time management as a barrier, which fell into the theme of cost-benefit barriers. An online instructor has unique challenges that differ from those of a face-to-face instructor, and time commitment has been acknowledged as one of those challenges that contribute to barriers to faculty adoption of online teaching (Bacow et al., 2012; Bolliger \& Wasilik, 2009; Giles et al,, 2014; Van de Vord \& Pogue, 2012).

Research on student satisfaction and retention in online learning may offer insights into why time commitment is an issue for online faculty (Hart, 2012; Lee \& Choi, 2011). Students report higher satisfaction and are more likely to be retained when faculty are engaged, responsive, and provide substantive feedback (Lewis \& Abdul-Hamid, 2006; Sher, 2009). However, being engaged and responsive, and giving substantive feedback while facilitating an online course can be time-consuming tasks for faculty. Additionally, designing quality courses for online delivery requires a significant time investment that may offer faculty little 


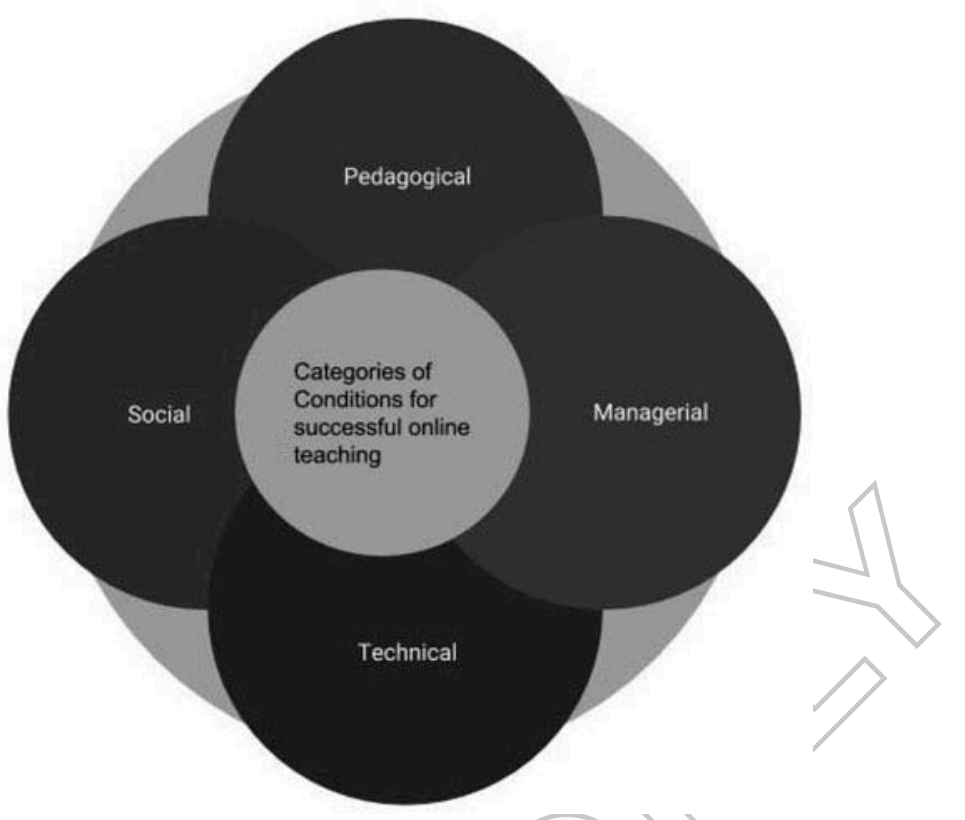

Q4 Figure 1. Categories of conditions for successful online teaching, adapted from Berge (1995)

perceived return on investment. Several researchers have identified faculty concerns about workload and compensation as discouraging factors for teaching online (Bacow et al., 2012; Bolliger \& Wasilik, 2009; Green et al., 2009). However, there is little research on how online instructors can manage their time to minimize these concerns. Our study investigated the perceived helpfulness of online instructor time management strategies.

\section{Theoretical framework}

Our study used a framework created by Berge (1995), who outlined four categories of necessary strategies for successful online teaching: managerial, pedagogical, technical, and social. The framework was used to identify and categorize time management strategies of online faculty because it purposefully defines categories that distinguish instruction from information delivery. Online instruction is broader than organizing and presenting content; there is a purposeful intent by the instructor in online course design to elicit engagement with the course materials and learners.

Managerial strategies are the procedural or administrative tasks required of an online course. Pedagogical strategies are tasks surrounding facilitating an online course either in the design or delivery phases. Technical strategies are efforts to make the technology transparent and helpful instead of a barrier to learning. Social strategies are efforts to create a friendly environment that promotes human relationships. Time-saving strategies in each of the four categories were identified through an extensive literature review and interviews with expert online faculty. 


\section{Managerial strategies}

Berge (1995) identified management strategies for computer-mediated communication, which at the time was mostly synchronous chats or asynchronous discussions with students. However, many of the strategies can translate into the robust asynchronous learning environments of today, such as responsiveness, procedural leadership, clarity, planning, preparation time, and online teaching experience. Current research, which collected advice from experienced online instructors, supports these strategies as being effective for asynchronous online teaching (Dunlap \& Lowenthal, 2018). Sheridan and Kelly (2010) investigated important behaviors of online instructors, finding that the most important were making requirements clear and being responsive to student needs. These behaviors fall into the managerial category and are consistent with workload concerns since both tasks can take an exorbitant amount of time. However, there is little empirical evidence of how these strategies assist with faculty time management.

Mandernach et al. (2013) investigated the time commitments of online faculty and discovered that online faculty spend more than 40 hours a week facilitating online courses to ensure effectiveness. Most of that time was spent providing feedback and communicating with students. Several researchers have identified that the use of course announcements (as a way to stay connected with students and also to provide useful information) helps students feel comfortable and leads to higher rates of student satisfaction in online courses (Dykman \& Davis, 2008b; Majeski \& Stover, 2007; Zhao et al., 2009).

Conrad (2016) analyzed students' and instructors perceptions of feedback in an asynchronous online course and found that, while students found collective feedback helpful, specific, detailed, and personalized feedback was more helpful. Using collective feedback can save instructors time by avoiding writing the same feedback over and over for individual students. Similarly, reusing feedback from other iterations of the course or from other students may also be a time-saver. In either case, instructors could spend time personalizing feedback comments instead of regenerating similar comments. Additionally, periodic course announcements could be a venue to provide collective feedback in addition to course information and reminders such as a synopsis of a discussion that highlights a few student posts along with general comments.

Scheduling time to reflect and learn new strategies can improve online course design and teaching practices, which in turn may save time during the facilitation of the course. Schmidt et al. (2016) noted that training is essential for successful online teaching, while Baran et al. (2011) suggested that continuous reflection can transform the understanding of processes related to online learning. While this integration of reflection may increase the time commitment during the design of the course, it can reduce time-consuming tasks during delivery. Based on the research evidence, our study included the following timesaving managerial strategies: sending or posting periodic course announcements, providing collective feedback, reusing feedback from previously used or saved feedback, scheduling time to facilitate the course, and scheduling time to learn and apply new strategies.

\section{Pedagogical strategies}

Berge (1995) identified pedagogical strategies for successful online computer-mediated 
synchronous online environments, some translate to the design of effective asynchronous environments, such as including clear objectives, encouraging participation, and making material relevant. More recently, Jaggars and $\mathrm{Xu}$ (2016) suggested that the quality of interaction relates significantly and positively to student achievement, particularly the student-to-instructor interaction, and this directly relates to encouraging participation. Trammel and LaForge (2017) asserted that careful course design, consistent structure, and due dates can mitigate frustrations for online students and instructors. Relieving frustration may also save faculty time during course facilitation by preventing student confusion and questions.

Content development has become easier with advances in technology. This has created momentum around sharing existing content. Open educational resources (OER) promote shared access to existing instructional materials (Wiley et al., 2014). Caudill (2011) stated that using OER can ensure a quicker course development process because it enables faculty to mix in existing resources instead of creating instructional material from scratch.

Clear and consistent navigation and course structure have been recommended best practices in online course design since the inception of course quality rubrics (MarylandOnline, 2018). The latest edition of the Quality Matters rubric addresses the organizational and technical aspects of course navigation and structure. Ralston-Berg et al. (2015) investigated student perceptions of online course quality best practices and found that students valued clear instructions and ease of navigation to ensure their success in online courses. However, research has not yet examined how these strategies relate to time management for the instructor. One can speculate that if students can locate necessary course materials without assistance, this may relieve frustration and save time for the instructor and the student.

Taylor et al. (2015) tested orientation videos in courses with high withdrawal rates and broad grade distributions and saw improvements on both measures after the orientation videos were introduced. Walker et al. (2016) investigated faculty use of the learning management system (LMS) and the grade center. They highlighted the LMS as a mechanism to enable the management of student information in addition to a communication tool to keep students updated on their progress. Using the grade center saves faculty time because it enables students to track their own grades and progress within the course. Our study investigated the perceived helpfulness of the following pedagogical strategies: scheduling time to design the course, using existing materials such as OER or publisher resources, creating clear and consistent navigation, organizing content into modules or units, creating a course orientation (video or text, quiz or scavenger hunt), establishing clear and specific expectations (e.g., to-do list, rubrics), and establishing a grading system that the LMS grade center supports.

\section{Technical strategies}

Although some of the strategies identified by Berge (1995) are still applicable, our study found that technical strategies are in need of updating due to the rapid evolution of technology over the last 20 years. However, the strategies of using new methods to indicate feedback and promoting peer learning can translate into many technologies used today. The LMS has been introduced and become more robust over time. Utilizing the instructional tools available can make online courses more effective and be time- 
savers for faculty if used effectively. According to Walker et al. (2016), the LMS features that benefited faculty in their teaching processes and quality of instruction were the gradebook, assessment tool, content creation tools, communication tools, and the interface of the LMS. However, technical issues with these tools became a hindrance to their online teaching process and instructional quality. Schoonenboom (2014) investigated why faculty use some LMS tools more than others and found that low intention use can be explained by low task importance, low tool usefulness, and/or low ease of use. Although these results do not specifically deal with time management, technical issues and the ease of use of tools suggest more use of time spent to resolve issues or learn the tools. However, once the technical tools are learned and working properly, they may save the instructor time.

In addition to LMS-specific tools, strategies in this category included providing audio or video feedback, using collaboration tools, and applying learning analytics techniques. Providing video or audio feedback can be more efficient and more personal than typing verbose feedback to students. Grigoryan (2017) found that multimodal feedback can also be more effective for student learning outcomes. The use of collaboration tools can provide faculty the ability to monitor progress as well as provide feedback during project development (Kai-Wai Chu \& Kennedy, 2011). This may save the instructor time in providing feedback to the students in making revisions at the completion of projects. Learning analytics data retrieved from the LMS can assist faculty in providing personalized corrective feedback (Tempelaar et al., 2015). Leveraging technology tools to use time efficiently and effectively are the focus of these strategies. Our study investigated the perceived helpfulness of the following technical strategies: using LMS-embedded tools to create multimedia content such as lecture videos and podcasts, using LMS features for assessment (e.g., quizzes, assignments, exam), using the LMS gradebook to enable students to track grades, using collaborative tools (e.g., wikis, blogs, Google Drive, Dropbox), using technology to provide feedback (audio or video), using LMS data or reports to track student engagement and participation, and using the LMS calendar functionality for automatic reminders and notifications.

\section{Social strategies}

Berge's (1995) social strategies include some applicable strategies for today's online learning environments, such as using introductions as well as facilitating interactivity and cultural sensitivity. These strategies leverage social interaction among course participants for feedback, support, and questions, which can save the instructor time during course facilitation.

Jahng et al. (2010) investigated small-group versus whole-group collaboration and found that small-group collaboration had higher participation from those who lurked (read but did not participate) in whole-group collaboration. Oztok (2016) found that student-facilitated discussions helped students better understand online learning processes and increased interaction. Researchers have also found that virtual synchronous meetings can help build community and enhance interaction, although virtual office hours are scarcely used similarly to actual office hours (Li \& Pitts, 2009). Lowenthal et al. (2017) experimented with incorporating optional synchronous meetings in an asynchronous online course, finding that students who attended found them helpful and wished they were used in other courses. 
The social strategies investigated for our study were having students participate in smallgroup discussions, establishing peer-to-peer interaction through group activities such as group projects or student-moderated discussions, requiring students to provide feedback through peer evaluation, offering online synchronous sessions for assistance (office hours and help sessions), and using multiple channels of communication.

\section{Purpose of the study}

There is a multitude of research on effective online teaching strategies involving the design and facilitation of courses. However, incorporating those strategies effectively takes time, and there is little research on how online faculty can effectively reduce their workload and manage their time while staying effective. Our study examined faculty perceptions of the helpfulness of time management strategies used in online courses through the following research questions:

(1) Which time management strategies do faculty perceive helpful for online teaching?

(2) What are some time management strategies that faculty do not use or perceive to be least helpful?

(3) Is there a relationship between faculty demographic factors and their perceptions of time management strategies?

\section{Methods}

\section{Data sources}

This survey-based research study was conducted in the Spring of 2019. After the Institutional Review Board approved the study, we emailed online faculty through the Association of Educational Communications Technology membership email list (1900 members) to invite them to participate in a survey through SurveyShare. In addition, we also invited online faculty who teach at two Southeastern United States universities (755 faculty) through each institution's online faculty distribution list. A reminder was sent approximately 2 weeks after the initial email. There was no incentive provided for completion of the surveys. A total of 267 instructors responded to the survey, equaling a 10\% response rate. Of these responses, 11 entries were deleted (five respondents had not taught online, and six respondents had not completed more than $10 \%$ of the survey) resulting in 256 valid responses. The respondents were from 27 countries with most of them (219) from the United States. Table 1 includes several other demographic characteristics of the faculty respondents.

\section{Instrument}

A validated instrument to measure time management strategies of online faculty did not exist, so we (expert online instructors and instructional designers) created it (see Appendix). The development of the instrument occurred in a three-step process: (1) conducted an extensive literature review on time management strategies, (2) documented time management strategies used by the research team, and (3) conducted an expert review through consultation with other expert online instructors. The draft instrument 


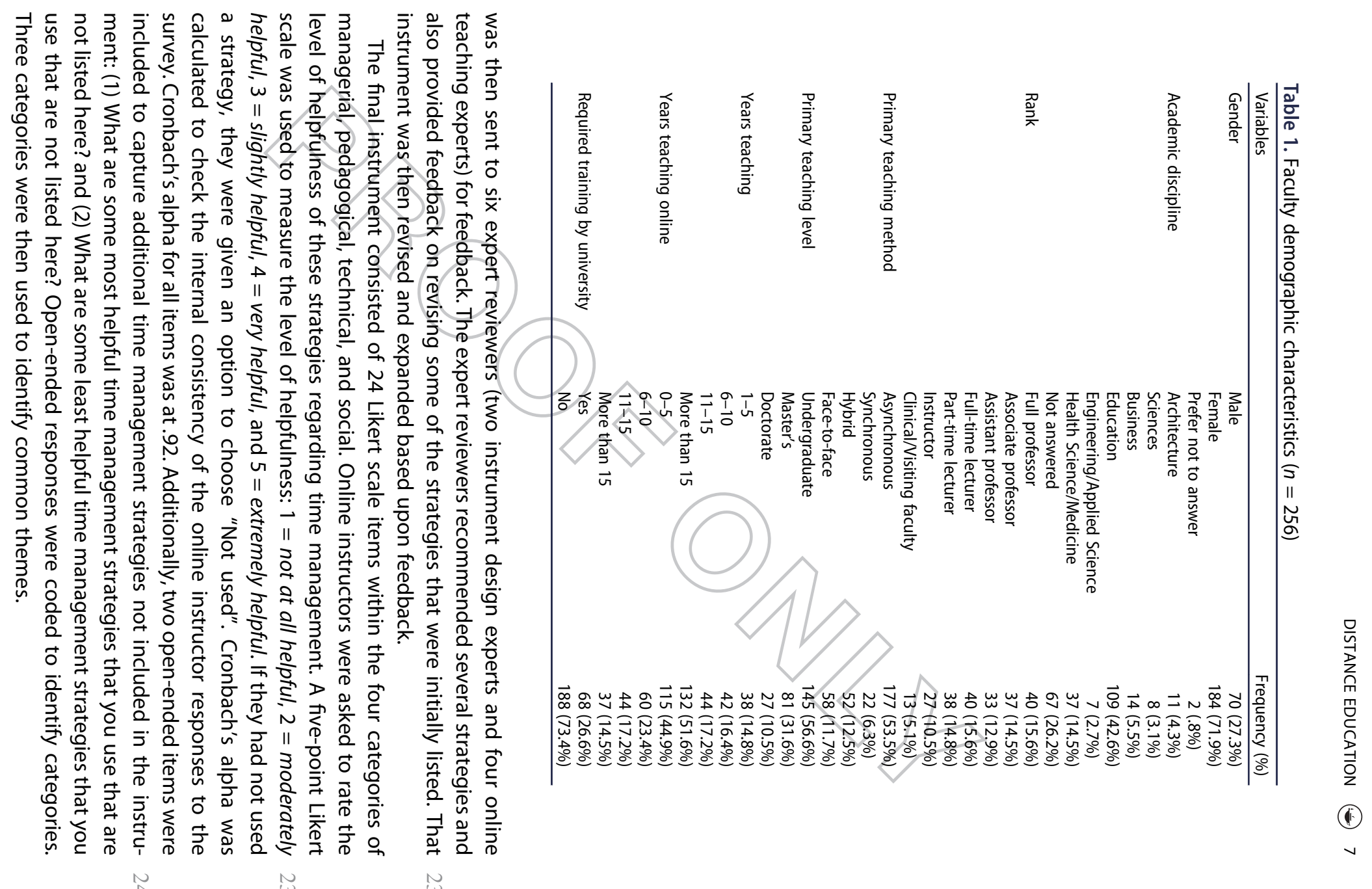




\section{Data analysis}

The data was reviewed for missing responses. Descriptive statistics (means and standard deviations) are used to report the perception of the faculty on the helpfulness of time management strategies. The descriptive statistics are reported at the item level, at the subcategory level, and by demographic factors. Cronbach's alpha was used to check the internal consistencies of the responses to the survey items. Inferential statistics (MANOVA) were employed to examine the differences among faculty in their responses to the survey with respect to gender, rank, teaching experience, teaching online experience, primary level of teaching, primary delivery method, and required training. Effect sizes were calculated with a MANOVA (small $=.01$; moderate $=.06$; large $=.14$ ) to document the size of obtained differences (Cohen, 1988). The open-ended responses were coded inductively to identify themes of strategies. We used the constant comparative method (Glaser \& Strauss, 1967) to analyze the data.

\section{Results}

Table 2 provides the descriptive statistics of the item and categorical means and standard deviation. An initial screening item, "If the strategy was used", applied for each of the 24 items. If the respondent had not used the strategy and they checked this item, it was considered as missing data. Table 2 includes data on the percentage of strategies not used, percentage of strategies used, the frequency of strategies used, and the helpfulness mean with standard deviation.

\section{Helpful time management strategies}

For those who used the time management strategies, their perception of helpfulness was rated high, and all the items were rated either slightly helpful or very helpful. Among the categorical means, the pedagogical time management strategies were rated the highest $(M=4.00, S D=0.35)$, and the social time management strategies were rated the lowest, though they averaged to be moderately helpful $(M=3.49, S D=0.21)$. Managerial strategies was rated at $M=3.72, S D=0.27$, and technical strategies at $M=3.55, S D=0.33$. Among the 24 individual strategies, establishing clear and specific expectations $(M=4.32)$ was rated the highest, followed by organizing content into modules or units $(M=4.28)$, which were both pedagogical time management strategies. Using the LMS calendar functionality $(M=3.22)$ was rated the lowest, with the second lowest being offering online synchronous sessions $(M=3.25)$. All the strategies used by the instructors were rated above 3.00, which was the rating for slightly helpful. These strategies can be perceived to have assisted the instructor in managing time effectively in online teaching. In addition to the closed-ended items, the respondents were asked to identify some time management strategies that were helpful but not included on the list. Eleven categories of strategies were recommended to be effective in managing time with a frequency of 5 or more. Some of them were scheduling time for online course facilitation, grading and feedback strategies, front-end organization, and reusing the content and design (see Table 3 for the various strategies recommended as most helpful by the instructors in the open-ended question). 


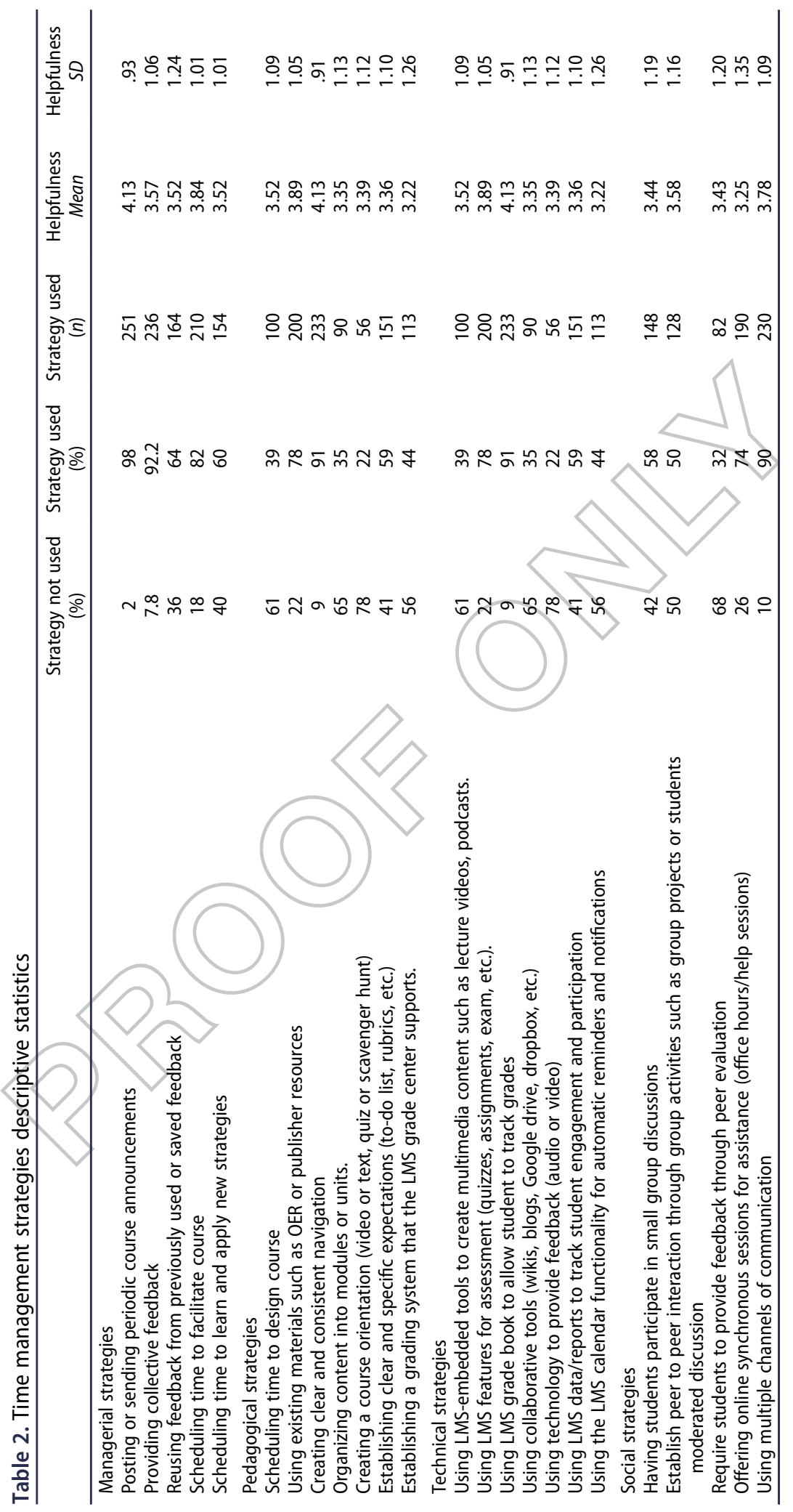




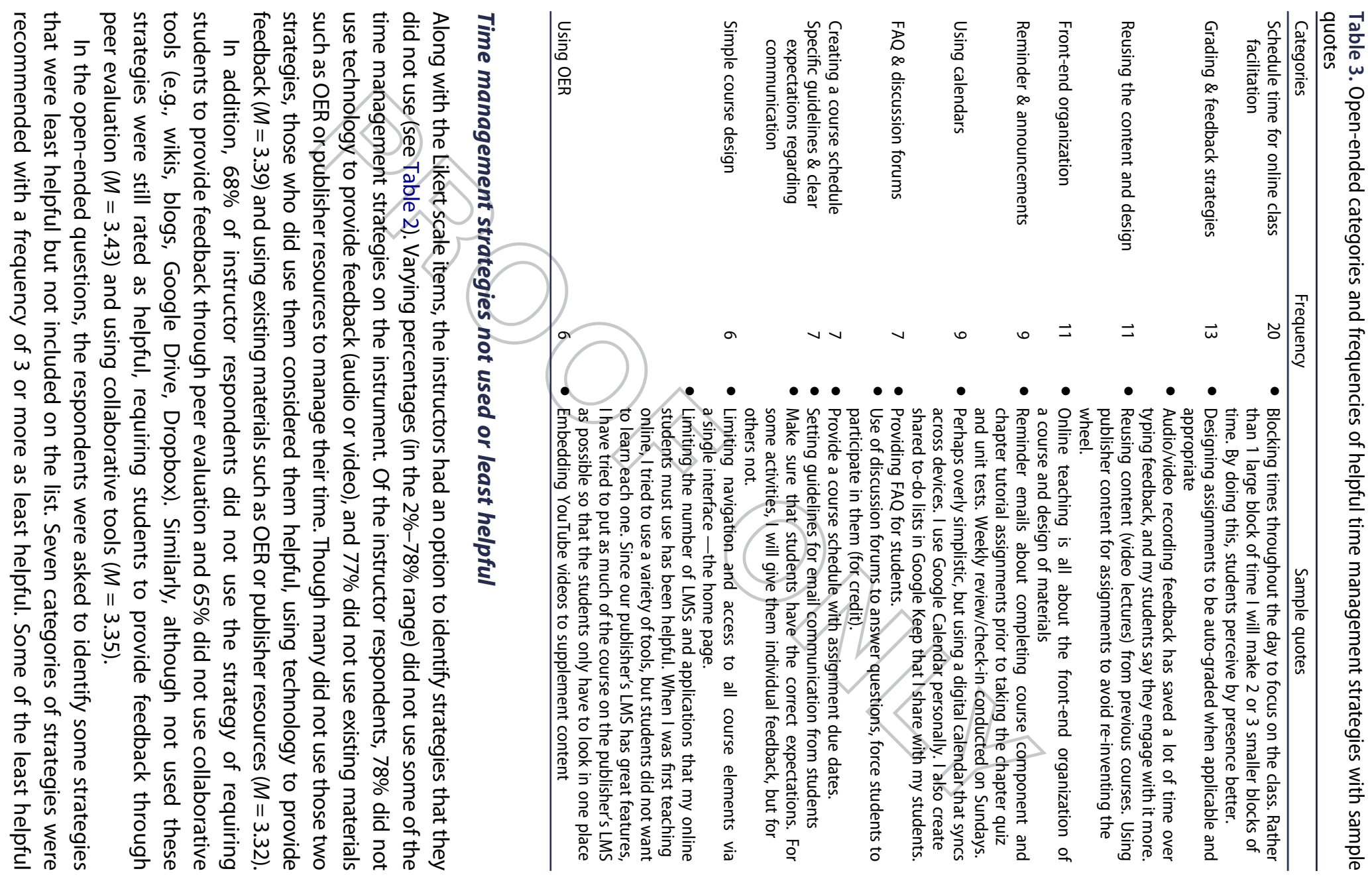




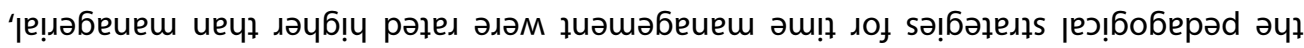

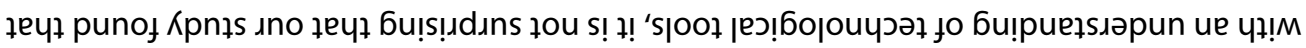

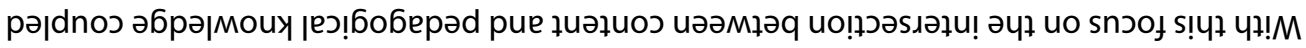

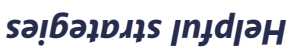

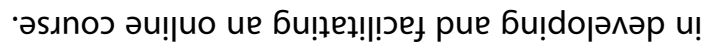

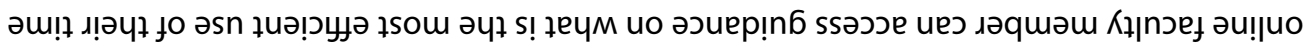

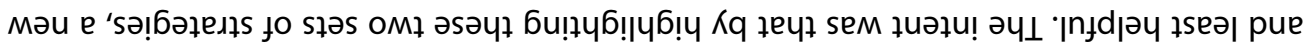

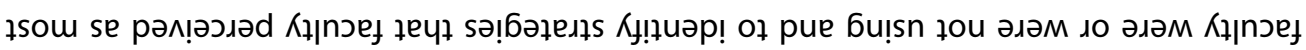

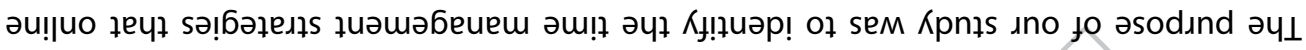

uo!̣snวs!a

(дวӘӊә ши!рәш)

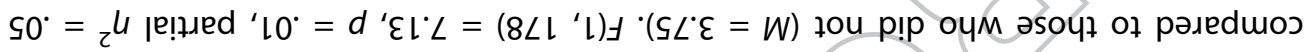

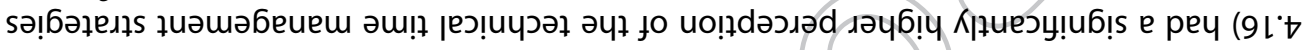

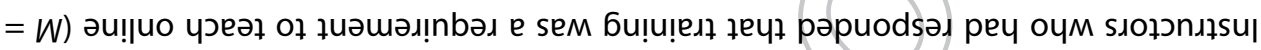

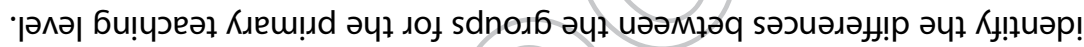

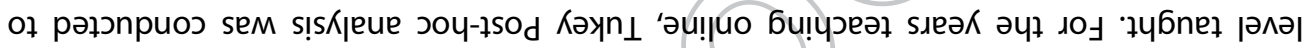

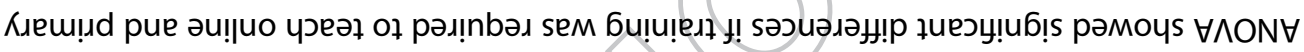

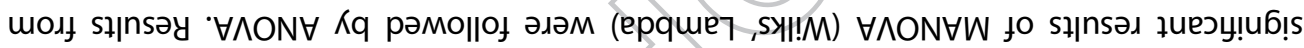

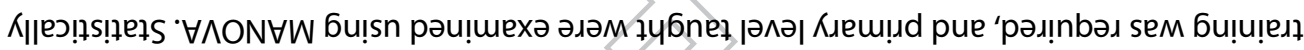
!! ‘әи!

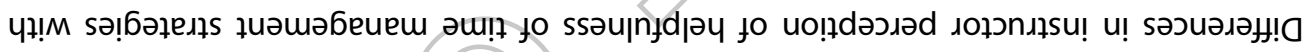

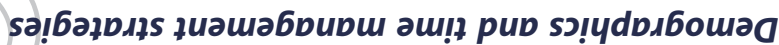

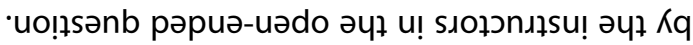

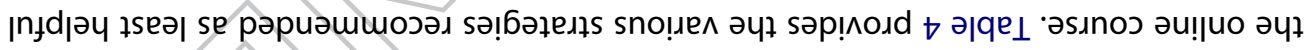

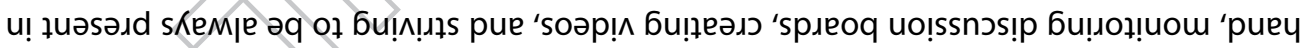

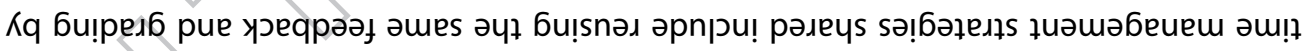

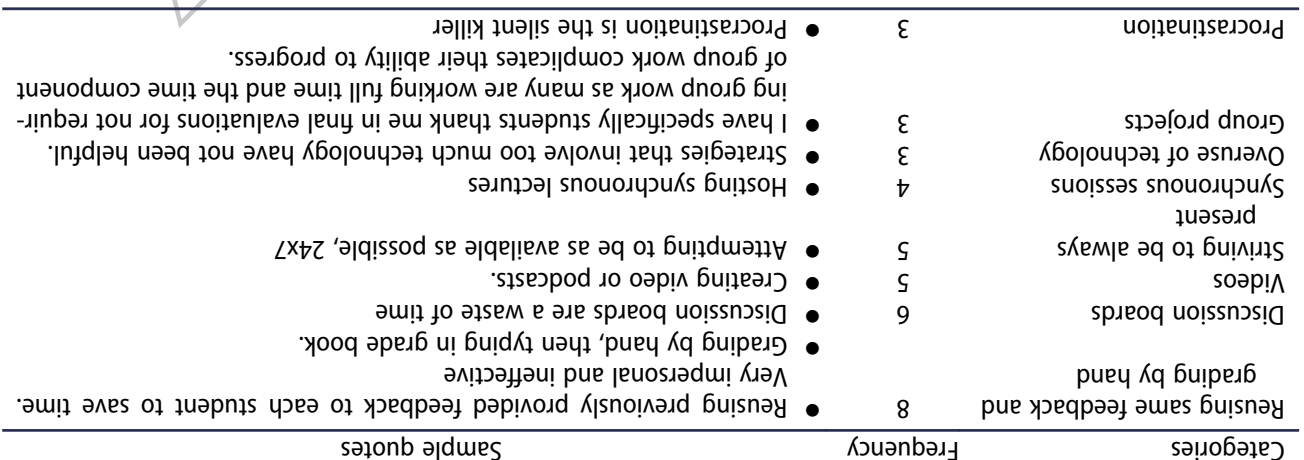

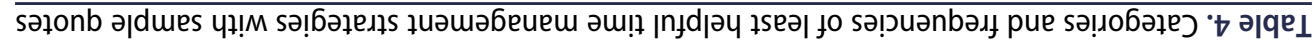


social, and technical strategies. Among the 24 time management strategies, seven were rated above 4.00. Among these seven, five were pedagogical, one was managerial, and one was technical. In the section below, we discuss the top five strategies recommended from closed-ended questions and top two strategies from open-ended comments that were rated as helpful.

\section{Setting expectations}

The pedagogical strategy rated as being most helpful was the creation of clear and consistent expectations (Borgemenke et al., 2013; Trammell \& LaForge, 2017). Design elements can be provided to support learners to take control of their learning by setting clear expectations, and this reduces the number of questions by the learner. Providing todo lists including the various tasks the learners are expected to complete as well as grading rubrics for activities and assignments makes the expectation clear to the learner and in turn results in fewer questions for the instructor. This strategy may take more time during the initial design of the course but will save time during facilitation and future iterations of the course.

\section{Organizing content}

Organizing content into modules or units (Borgemenke et al., 2013; Dykman \& Davis, 2008a; Li \& Irby, 2008; Trammell \& LaForge, 2017) was rated a helpful time management strategy. Borgemenke et al. (2013) suggested utilizing course modules or units within an online course to structure the overall course navigation and provide consistency in design. Although this strategy may take additional planning time at the outset, it makes it easier for students to find the information that they need and can aid in increasing facilitation time spent by the instructor by reducing the number of questions from students (Dykman \& Davis, 2008b; Renes \& Strange, 2011).

\section{Clear and consistent navigation}

Intuitive navigation is critical to an online course. Learners may be easily confused and spend time searching on asking questions when the course navigation is unclear. Instructors may also need to spend extra time responding to questions about the location of content and activities. Pierce (2015) recommended keeping the navigation predictable, simple, consistent, and hierarchical among several techniques for navigation usability.

\section{Periodic announcements}

Posting or sending periodic course announcements (managerial strategies) were also rated as helpful by respondents. This not only helps with instructor presence but also helps clarify each week's tasks and answer questions before they arise. Orlando and Howard (2018) discussed the importance of sending periodic course announcements for the learners to be successful. Martin et al. (2018) listed sending announcements as one of 12 facilitation strategies in online courses. When periodic announcements are sent, it not only helps the learner be successful but also helps in saving time for the instructor by reducing further questions and clarifications. 


\section{Online gradebook}

Additionally, using the LMS gradebook (technical strategies) was rated helpful for time management. Ko and Rossen (2017) recommended the use of online gradebook in online courses. Using the online gradebook assists the instructor in keeping all the grades in one place and tracking ungraded assignments and the due dates of upcoming assignments. It also provides an opportunity for students to review their grades periodically to track their performance without direct communication with the instructor.

An open-ended question sought the most helpful time management strategies of the instructors. Not surprisingly, pedagogical strategies such as scheduling time for online course development and utilizing grading and feedback strategies were mentioned most frequently. This aligns to research done by Trammell and LaForge (2017), who identified a practice within online education of using course shells to standardize the structure and delivery of courses within a program.

\section{Scheduling time for course facilitation}

This can present a challenge when it comes to online teaching because faculty may not be accustomed to designated specific times to facilitate the course and other activities can take priority on the calendar if time has not been blocked out specifically for course facilitation.

\section{Utilizing grading and feedback strategies}

Similar to using the online gradebook that was rated high in the closed ended question, grading requires time management. Using a variety of assessments-some with autograding - and reusing feedback are strategies that can be used to manage time in grading and providing feedback.

Although these strategies have been reported by several researchers, including Borgemenke et al. (2013) and Renes and Strange (2011), as being effective online instructional strategies, there is limited empirical support as to whether they are effective time management strategies. However, Cross and Polk (2018) suggested having faculty set a schedule, including response time expectations, and communicate it clearly to students. They also suggested automating as much as possible through technology, such as reusing content and using timed or automated announcements or email messages to save time.

\section{Strategies not used or perceived least helpful}

We also explored time management strategies that online faculty members were not using. The top three that were not used were using technology to provide feedback, using existing materials such as OER or publisher resources, and requiring students to provide feedback through peer evaluation.

\section{Using technology to provide feedback}

About $30 \%$ of the respondents were not leveraging technology to provide feedback in either video or audio form. Although technology is helpful in various aspects, instructors might perceive providing feedback in non-text format to be time-consuming and hence may not use this strategy in their online course. Among those who rated these, some still found it to be slightly helpful. Audio and video feedback can be time-savers and have the 
added benefit of providing more personalized feedback since learners can hear and see the instructor (Leibold \& Schwarz, 2015).

\section{Using existing resources}

Instructors were using OER or publisher resources to manage their time. And while $30 \%$ of instructors who responded reported they were not using either of these strategies, the findings indicated those who used the strategies found them to be slightly helpful for time management in course design and development because they adapted the content instead of creating it from scratch. Not adopting OER or publisher content can be attributed to unfamiliarity with the tools available for online instruction and may be linked to the lack of adequate training or preparation and lack of experience in teaching in online environments (Power \& Morven-Gould, 2011; Renes \& Strange, 2011; Roy \& Boboc, 2016; Schmidt et al., 2016; Windes \& Lesht, 2014).

\section{Peer evaluation}

Requiring students to provide feedback through peer evaluation was another strategy that about $26 \%$ of instructors rated as one that they were not using. There could be various reasons why this strategy may not be applicable to all online courses. Although peer evaluation is very helpful in graduate-level courses (Landry et al., 2015), undergraduate students may not be prepared to provide quality evaluations. Again, although these strategies were not used by many of the respondents, those who were using them rated them as helpful for time management.

Conversely, some of the less helpful time management strategies from the open-ended comments were reusing the same feedback and grading by hand.

\section{Reusing same feedback}

Although reusing the same feedback from previous years may be considered to save time for instructors, this was rated as least helpful and considered it to be impersonal and ineffective. However, Lewis and Abdul-Hamid (2006) suggested creating a feedback bank of frequently used feedback, cutting and pasting appropriate comments, and then constructing personalization around the reused comments. This strategy could save time and be personal.

\section{Grading by hand}

Understandably so, grading by hand would not be an efficient time management strategy. As our study highlighted, $76 \%$ of respondents indicated that they were using a grading system that was supported by the LMS grade center. As instructors leverage more of the LMS features to facilitate their course, they will also find it efficient to track grades and utilize the grade center functions.

With these latter time management strategies, instructors must find the right balance between effectively managing their time and also creating engagement opportunities for the students (Gray \& DiLoreto, 2016). Also, though some of these strategies mentioned in the closed-ended survey were not used by some instructors, they were still considered slightly helpful by those who were using them. In addition, the strategies perceived as least helpful in the open-ended responses had low frequencies. These results have to be interpreted carefully. 


\section{Demographic factors}

The final research question explored the relationship between faculty demographic factors and their perceptions of time management strategies. The findings suggest that there are significant differences based on instructor training required to teach online and based on primary level taught. Those who were required to complete training prior to teaching online reported having higher perceptions of technical time management strategies when compared to those who had not completed any training. This further substantiates the need to focus on online faculty development and that the transition from face-to-face to online instruction requires a specialized set of skills which requires training and additional resources (Baran et al., 2013; Herman, 2012).

\section{Implications}

Our study has several implications for online instructors. First, pedagogical components of online course instruction require time and attention. Although many of these components, such as consistent course navigation and a clear, well-outlined syllabus, require significant upfront time investments from instructors, the overall benefits will be a more seamless instructional experience. Students will understand expectations and what success looks like in their course, which may decrease time spent during facilitation of the course. Strategies such as peer evaluation and synchronous sessions may not be as effective time management strategies for online instructors. Student schedules and availability influence the effectiveness of these strategies. Often, students enroll in asynchronous courses for convenience due to personal or work demands. These demands may interfere with a student's ability to schedule time to work together for peer evaluation. There also is a learning curve for peer evaluation, which may present additional time constraints and demands both on the instructor and the students. Scheduling a synchronous meeting for an asynchronous course can also be difficult, particularly for students expecting that the course will enable them to complete their assignments on a flexible schedule. These are just a few of the reasons that these specific strategies may not be utilized as much for online instructors.

Our study also has implications for instructional designers who assist instructors in designing online courses. For many of these time management strategies, there is an initial upfront time investment. Instructional designers will need to explain to novice online faculty that this upfront time investment will yield more efficiency throughout their course facilitation. The first iteration of a course may appear to involve significantly more time invested in course development, but with each subsequent iteration online instructors will see more effective time utilization. Our study provides the empirical support that instructional designers can share with these novice instructors to encourage them to devote the time in leveraging these different strategies.

\section{Limitations and future research}

There were some limitations to this survey-based research study. First, the response rate to the survey was only $10 \%$. Second, the findings on time management strategies are from self-reported data. There could be a response bias from the respondents. Thirdly, the survey does not include an exhaustive list of all the time management strategies. Fourth, the respondents included strategies that were on the instrument to open-ended items 
though we requested strategies that were not on this list. Finally, online learning contexts vary globally. It is vital to interpret the results with caution as these time management strategies may not be generalizable to all contexts and settings.

Future research studies could use this survey in various contexts. Future validation studies of the instrument will also be beneficial to confirm if the instrument measures these strategies as designed. Future research should strive to include strategies that are not included in our study and interview faculty who teach online to identify what strategies support them in their context.

\section{Conclusion}

Time management strategies for online faculty can be helpful in optimizing efficiency without jeopardizing effectiveness. The results from our study indicate the importance of several time management strategies that may assist online instructors in, for example, providing clear and consistent expectations and well-organized course content. These strategies are consistent with the recommendations of Shi et al. (2006), who recommended six time management strategies for online instructors, and although these strategies are dated, our results still align well with them: (1) write clearly and concisely, (2) organize information in an easy to follow order, (3) be explicit and empathetic about the time requirements in the syllabus, (4) manage asynchronous discussions, (5) take advantage of technical tools available, and (6) utilize other resources. More recently, Raffo et al. (2015) suggested finding a balance of time to devote to four facets of online teaching: course design and development, course delivery, assessment and feedback, and professional development. The recommendations from both Shi (2006) and Roffo et al. (2015) fall mostly under pedagogical and managerial time management strategies. Course design and development aligns with the pedagogical strategies perceived as helpful in the results of our study. Online faculty who invest the time to carefully and thoughtfully design and develop their course may save time during delivery.

\section{Notes on contributors}

Beth Oyarzun is a Clinical Assistant Professor of Learning, Design and Technology at the University of North Carolina at Charlotte. She teaches fully asynchronous online learning, design and technology courses. Her research interests include effective online pedagogy, collaborative online learning, and social presence. Additional details can be found at https://sites.google.com/uncc.edu/bethoyarzun/.

Florence Martin is a Professor in Learning, Design and Technology at the University of North Carolina at Charlotte. She teaches $100 \%$ online and engages in research focusing on the effective design of instruction and integration of digital technology to improve learning and performance. More details about her can be found at http://www.florencemartin.net/.

Robert L. Moore is an Assistant Professor in Instructional Design and Technology at Old Dominion University. He teaches synchronous distance learning courses, focusing his research on participatory online learning environments, and using learning analytics to examine learner engagement in massive open online courses. Connect with him at http://www.twitter.com/robmoore3.

\section{ORCID}

Beth Oyarzun (iD http://orcid.org/0000-0001-7886-8190

Florence Martin (D) http://orcid.org/0000-0002-6055-5636

Robert L. Moore (ID http://orcid.org/0000-0002-5645-9297 


\section{References}

Bacow, L. S., Bowen, W. G., Guthrie, K. M., Long, M. P., \& Lack, K. A. (2012). Barriers to adoption of online learning systems in US higher education (Research Report). Ithaka. https://doi.org/10.18665/ sr.22432

Baran, E., Correia, A. P., \& Thompson, A. (2011). Transforming online teaching practice: Critical analysis of the literature on the roles and competencies of online teachers. Distance Education, 32(3), 421-439. https://doi.org/10.1080/01587919.2011.610293

Baran, E., Correia, A. P., \& Thompson, A. (2013). Tracing successful online teaching in higher education: Voices of exemplary online teachers. Teachers College Record, 115(3), 1-41. Retrieved from http://www.tcrecord.org/content.asp?contentid=16896

Berge, Z. L. (1995). Facilitating computer conferencing: Recommendations from the field. Educational Technology, 35(1), 22-30. Retrieved from https://www.jstor.org/stable/44428247

Bolliger, D. U., \& Wasilik, O. (2009). Factors influencing faculty satisfaction with online teaching and learning in higher education. Distance Education, 30(1), 103-116. https://doi.org/10.1080/ 01587910902845949

Borgemenke, A. J., Holt, W. C., \& Fish, W. W. (2013). Universal course shell template design and implementation to enhance student outcomes in online course work. Quarterly Review of Distance Education, 14(1), 17-23. Retrieved from https://www.infoagepub.com/qrde-issue.html? $\mathrm{i}=\mathrm{p} 54 \mathrm{c} 3 \mathrm{c} 3 \mathrm{dc} 75 \mathrm{eb} 8$

Caudill, J. (2011, April 12-14).Using Open Course Ware to enhance on-campus educational programs [Paper presentation]. In C. P. Ho (Ed.), Emerging Technologies: Making it Work: Proceedings of the 16th Annual Technology, Colleges and Community Worldwide Online Conference (pp. 43-47). University of Hawaii. Retrieved from https://tccpapers.coe.hawaii.edu/archive/2011/Caudill.pdf

Cohen, J. (1988). Statistical power analysis for the behavioral sciences. Erlbaum.

Conrad, S. (2016). Student and instructor perceptions of feedback in asynchronous online learning: A mixed-methods study (Publication No. 1934108253) [Doctoral dissertation, George Mason University]. ProQuest Dissertations \& Theses Global.

Cross, T., \& Polk, L. (2018). Burn bright, not out: Tips for managing online teaching. Journal of Educators Online, 15(3), 1-6. Retrieved from https://www.thejeo.com/archive/2018_15_3/cross_ polk

Dunlap, J., \& Lowenthal, P. (2018). Online educators' recommendations for teaching online: Crowdsourcing in action, Open Praxis, 10(1), 79-89. Retrieved from https://openpraxis.org/ open prax/index.php/OpenPraxis/article/view/721

Dykman, C. A., \& Davis, C. K. (2008a). Part two: Teaching online versus teaching conventionally. Journal of Information Systems Education, 19(2), 157-165. Retrieved from http://jise.org/ Volume19/n2/JISEv19n2p157.html

Dykman, C. A., \& Davis, C. K. (2008b). Part three: A quality online educational experience. Journal of Information Systems Education, 19(3), 281-290. Retrieved from http://jise.org/Volume19/n3/ JISEv19n3p281.html

Giles, M., Ritter, R., Zimmerman, E., \& Kaiser, B. (2014, March 17). Faculty experiences with online learning: A mixed methods study. In M. Searson \& M. N. Ochoa (Eds.), Society for Information Technology \& Teacher Education International Conference (pp. 315-323). Association for the Advancement of Computing in Education. Retrieved from https://www.learntechlib.org/p/ 130764/

Glaser, B. G., \& Strauss, A. L. (1967). The discovery of grounded theory: Strategies for qualitative research. Aldine de Gruyter.

Gray, J. A., \& DiLoreto, M. (2016). The effects of student engagement, student satisfaction, and perceived learning in online learning environments. International Journal of Educational Leadership Preparation, 11(1), 98-119. Retrieved from https://www.icpel.org/uploads/1/5/6/2/ 15622000/ijelp_volume_11_number_1_spring_2016_.pdf

Green, T., Alejandro, J., \& Brown, A. H. (2009). The retention of experienced faculty in online distance education programs: Understanding factors that impact their involvement. The International 
Review of Research in Open and Distributed Learning, 10(3). https://doi.org/10.19173/irrodl.v10i3. 683

Grigoryan, A. (2017). Feedback 2.0 in online writing instruction: Combining audio-visual and text-based commentary to enhance student revision and writing competency. Journal of Computing in Higher Education, 29(3), 451-476. https://doi.org/10.1007/s12528-017-9152-2

Hart, C. (2012). Factors associated with student persistence in an online program of study: A review of the literature. Journal of Interactive Online Learning, 11 (1). Retrieved from http://www.ncolr. org/jiol/issues/pdf/11.1.2.pdf

Herman, J. H. (2012). Faculty development programs: The frequency and variety of professional development programs available to online instructors. Journal of Asynchronous Learning Networks, 16(5), 87-106. Retrieved from https://onlinelearningconsortium.org/read/journalissues/

Jaggars, S. S., \& Xu, D. (2016). How do online course design features influence student performance? Computers \& Education, 95, 270-284. https://doi.org/10.1016/j.compedu.2016.01.014

Jahng, N., Nielsen, W., \& Chan, E. K., \& (2010). Collaborative learning in an online course: A comparison of communication patterns in small and whole group activities. The Journal of Distance Education, 24 (2), 39-58. Retrieved from https://www.learntechlib.org/p/54734/

Kai-Wai Chu, S., \& Kennedy, D. M. (2011). Using online collaborative tools for groups to co-construct knowledge. Online Information Review, 35(4), 581-597. https://doi.org/10.1108/ 14684521111161945

Ko, S., \& Rossen, S. (2017). Teaching online: A practical guide (4th ed.). Routledge. https://doi.org/10. 4324/9780203427354

Landry, A., Jacobs, S., \& Newton, G. (2015). Effective use of peer assessment in a graduate level writing assignment: A case study. International Journal of Higher Education, 4(1), 38-51. https:// doi.org/10.5430/ijhe.v4n1p38

Lee, Y., \& Choi, J. (2011). A review of online course dropout research: Implications for practice and future research. Educational Technology Research and Development, 59(5), 593-618. https://doi. org/10.1007/s11423-010-9177-y

Leibold, N., \& Schwarz, L. M. (2015). The art of giving online feedback. The Journal of Effective Teaching, 15(1), 34-46. Retrieved from https://uncw.edu/jet/articles/vol15_1/leiboldabs.html

Lewis, C. C., \& Abdul-Hamid, H. (2006). Implementing effective online teaching practices: Voices of exemplary faculty. Innovative Higher Education, 31(2), 83-98. https://doi.org/10.1007/s10755-0069010-z

Li, C.-S., \& Irby, B. (2008). An overview of online education: Attractiveness, benefits, challenges, concerns and recommendations. College Student Journal, 42(2), 449-458. Retrieved from https:// www.questia.com/library/p1917/college-student-journal/i2740309/vol-42-no-2-june

Li, L., \& Pitts, J.P. (2009). Does it really matter? Using virtual office hours to enhance student-faculty interaction. Journal of Information Systems Education, 20(2), 175-185. Retrieved from https://jise. org/Volume20/n2/JISEv20n2p175.html

Lloyd, S. A., Byrne, M. M., \& McCoy, T. S. (2012). Faculty-perceived barriers of online education. Journal of Online Learning and Teaching, 8 (1). Retrieved from https://jolt.merlot.org/vol8no1/ abstracts.htm

Lowenthal, P.R., Snelson, C., \& Dunlap, J.C. (2017). Live synchronous web meetings in asynchronous online courses: Reconceptualizing virtual office hours. Online Learning 21(4), 177-194. https://doi. org/10.24059/olj.v21i4.1285

Majeski, R., \& Stover, M. (2007). Theoretically based pedagogical strategies leading to deep learning in asynchronous online gerontology courses. Educational Gerontology, 33(3), 171-185. https://doi. org/10.1080/03601270600850826

Mandernach, B. J., Hudson, S., \& Wise, S. (2013). Where has the time gone? Faculty activities and time commitments in the online classroom. Journal of Educators Online, 10(2), 1-15. Retrieved from https://www.thejeo.com/archive/2013_10_2/mandernach_hudson_wise

Martin, F., Wang, C., \& Sadaf, A. (2018). Student perception of helpfulness of facilitation strategies that enhance instructor presence, connectedness, engagement and learning in online courses. The Internet and Higher Education, 37, 52-65. https://doi.org/10.1016/j.iheduc.2018.01.003 
MarylandOnline. (2018). Specific review standards from the QM higher education rubric (6th ed.). h t t ps:// w w w. qualitymatters.org/sites/default/files/PDFs/ StandardsfromtheQMHigherEducationRubric.pdf

Orlando, M., \& Howard, L. (2018). Setting the stage for success in an online learning environment. In F. Giuseffi (Ed.), Emerging self-directed learning strategies in the digital age (pp. 1-9). IGI Global. https://doi.org/10.4018/978-1-5225-3465-5.ch001

Oztok, M. (2016) Reconceptualizing the pedagogical value of student facilitation. Interactive Learning Environments, 24(1), 85-95. https://doi.org/10.1080/10494820.2013.817440

Pierce, P. (2015, September 28). 10 Guidelines for navigation usability. Usability Geek. Retrieved from https://usabilitygeek.com/10-guidelines-for-navigation-usability/

Power, T. M., \& Morven-Gould, A. (2011). Head of gold, feet of clay: The online learning paradox. The International Review of Research in Open and Distributed Learning, 12(2), 19-39. https://doi.org/10. 19173/irrodl.v12i2.916

Raffo, D. M., Brinthaupt, T. M., Gardner, J. G., \& Fisher, L. S. (2015). Balancing online teaching activities: Strategies for optimizing efficiency and effectiveness. Online Journal of Distance Learning Administration, 18(1). Retrieved from https://www.westga.edu/ distance/ojdla/ spring181/raffo_brinthaupt_gardner_fisher181.html

Ralston-Berg, P., Buckenmeyer, J., Barczyk, C., \& Hixon, E. (2015). Students' perceptions of online course quality: How do they measure up to the research? Internet Learning, 4(1), 38-55. Retrieved from http://www.ipsonet.org/publications/open-access/journal-of-online-learning-research-andpractice/volume-4-number-1-spring-2015

Renes, S. L., \& Strange, A. T. (2011). Using technology to enhance higher education. Innovative Higher Education, 36(3), 203-213. https://doi.org/10.1007/s10755-010-9167-3

Roy, M., \& Boboc, M. (2016). Professional development needs of online teachers. Journal of Online Learning Research, 2(3), 283-302. Retrieved from https://www.learntechlib.org/primary/p/ $172451 /$

Schmidt, S. W., Tschida, C. M., \& Hodge, E. M. (2016). How faculty learn to teach online: What administrators need to know. Online Journal of Distance Learning Administration, 19 (1). Retrieved from https://www.westga.edu/ distance/ojdla/spring191/schmidt_tschida_hodge191.html

Schoonenboom, J. (2014). Using an/adapted, task-level technology acceptance model to explain why instructors in higher education intend to use some learning management system tools more than others. Computers \& Education, 71, 247-256. https://doi.org/10.1016/j.compedu. 2013.09.016

Seaman, J. E., Allen, I. E., \& Seaman, J. (2018). Grade increase: Tracking distance education in the United States. Babson Survey Research Group. Retrieved from https://onlinelearningsurvey.com/reports/ gradeincrease.pdf

Sher, A. (2009). Assessing the relationship of student-instructor and student-student interaction to student learning and satisfaction in Web-based online learning environment. Journal of Interactive Online Learning, 8(2). Retrieved from https://www.ncolr.org/issues/jiol/v8/n2/asses sing-the-relationship-of-student-instructor-and-student-student-interaction-to-student-learning -and-satisfaction-in-web-based-online-learning-environment.html

Sheridan, K., \& Kelly, M. A. (2010). The indicators of instructor presence that are important to students in online courses. MERLOT Journal of Online Learning and Teaching, 6(4), 767-779. Retrieved from https://jolt.merlot.org/vol6no4/sheridan_1210.pdf

Shi, M., Bonk, C. J., \& Magjuka, R. J. (2006). Time management strategies for online teaching. International Journal of Instructional Technology and Distance Learning, 3(2), 3-10.

Taylor, J. M., Dunn, M., \& Winn, S. K. (2015). Innovative orientation leads to improved success in online courses. Online Learning, 19(4), 1-9. https://doi.org/10.24059/olj.v19i4.570

Tempelaar, D. T., Rienties, B., \& Giesbers, B. (2015). In search for the most informative data for feedback generation: Learning analytics in a data-rich context. Computers in Human Behavior, 47, 157-167. https://doi.org/10.1016/j.chb.2014.05.038

Trammell, B., \& LaForge, C. (2017). Common challenges for instructors in large online courses: Strategies to mitigate student and instructor frustration. Journal of Educators Online, 14(1), 10-19. Retrieved from https://www.thejeo.com/archive/2017_14_1/trammell_laforge 
Van de Vord, R., \& Pogue, K. (2012). Teaching time investment: Does online really take more time than face-to-face? The International Review of Research in Open and Distributed Learning, 13(3), 132-146. https://doi.org/10.19173/irrodl.v13i3.1190

Walker, D., Lindner, J., Murphrey, T., \& Dooley, K. (2016). Learning management system usage: Perspectives from University instructors. Quarterly Review of Distance Education, 17(2), 41-50, 61-63. Retrieved from https://www.infoagepub.com/qrde-issue.html?i=p57df1f950c4a0

Wiley, D., Bliss, T. J., \& McEwen, M. (2014). Open educational resources: A review of the literature. In M. Spector, M. Merrill, J. Elen, \& M. Bishop (Eds.), Handbook of research on educational communications and technology (pp. 781-789). Springer. https://doi.org/10.1007/978-1-46143185-5_63

Windes, D. L., \& Lesht, F. L. (2014). The effects of online teaching experience and institution type on faculty perceptions of teaching online. Online Journal of Distance Learning Administration, 17 (1). Retrieved from https://www.westga.edu/ distance/ojdla/spring171/windes_lesht171.html

Zhao, J. J., Alexander, M. W., Perreault, H., Waldman, L., \& Truell, A. D. (2009). Faculty and student use of technologies, user productivity, and user preference in distance education. Journal of Education for Business, 84(4), 206-212. https://doi.org/10.3200/JOEB.84.4.206-212

\section{Appendix: Time management strategies instrument}

\section{Time management strategies in online instruction}

The purpose of this survey is to assess the use and helpfulness of time management strategies in online instruction. The survey organizes the time management strategies into the following categories: (1) managerial, (2) pedagogical, and (3) technical and (4) social. If you have used the strategy, please rate the level of helpfulness in regards to time management. If you have not used the strategy, please select "Not used".

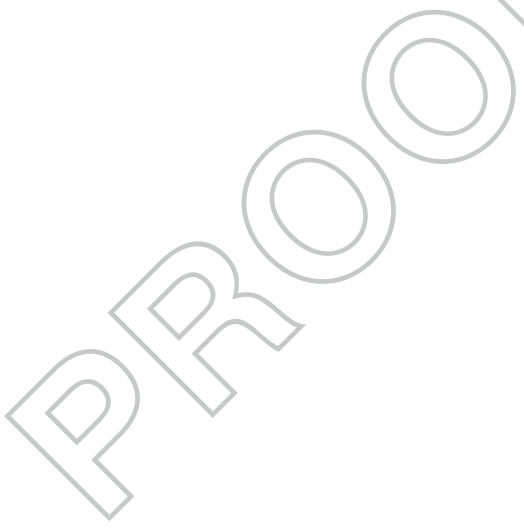




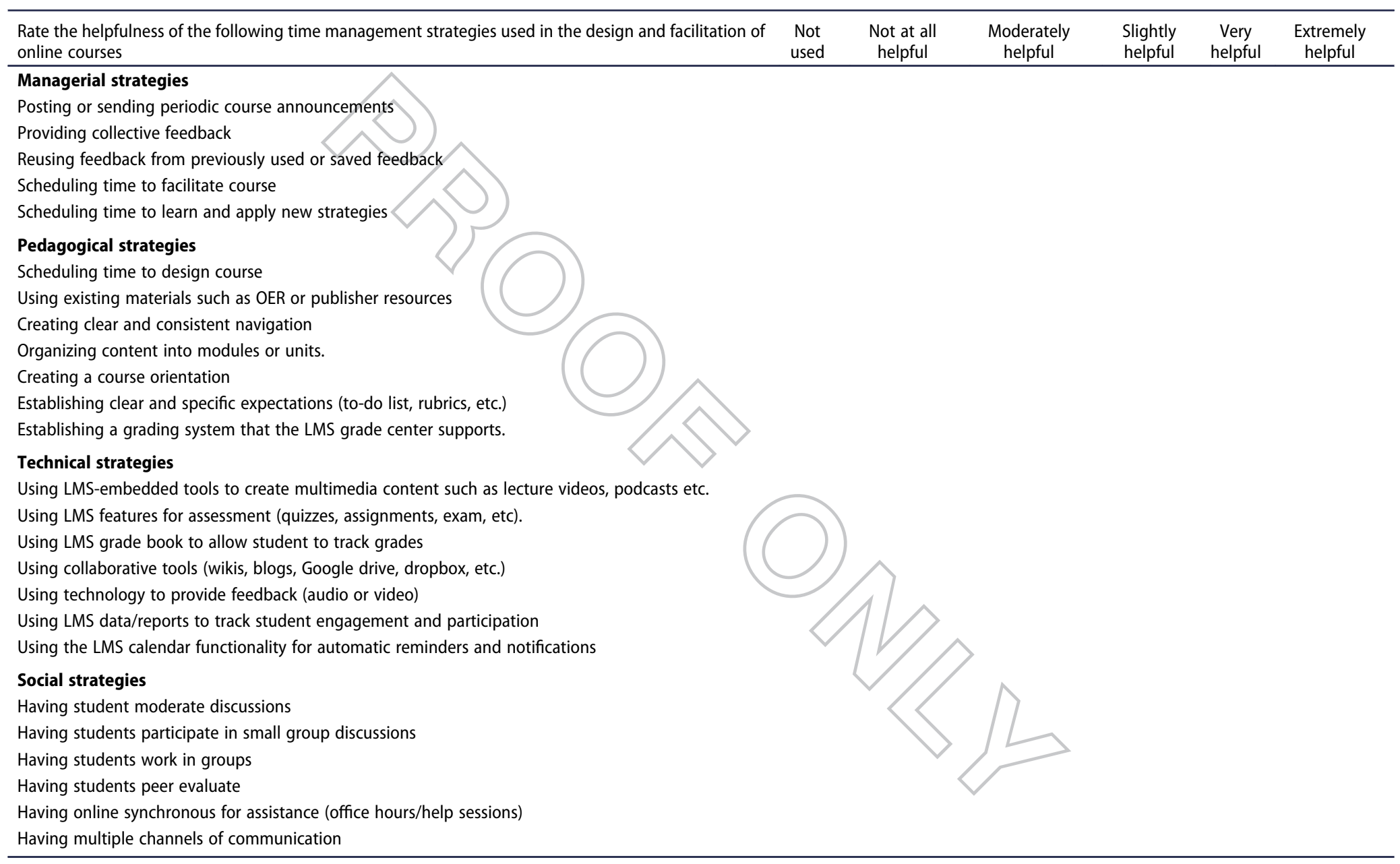


Instructions: Please type in your responses to the following questions.

12. What are some time management strategies that you use but not listed here and you have found 715 it helpful?

13. What are some time management strategies that you use but not listed here and you have found it least helpful? 